\title{
EFFECT OF DIFFERENT PRE-SOWING TREATMENT ON THE EMERGENCE OF DIALIUM GUINEENSE (WILD)
}

\author{
${ }^{1 \& 2}$ Abdulrahman A., ${ }^{2}$ Atiku M. ${ }^{2}$ Ambursa A.S., ${ }^{2}$ Umar I., ${ }^{2}$ Shuaibu A., ${ }^{2}$ Senchi, I. J. and ${ }^{2}$ Odedina, T. D. \\ 1. Department of Agricultural Technology, College of Agriculture and Animal Science, Bakura, \\ Zamfara state \\ 2. Department of Forestry and Fisheries, Kebbi State University of Science and Technology, Aliero, \\ Kebbi state \\ Corresponding author Email address : aasarki@gmail.com
}

\begin{abstract}
The experiments were conducted in the Forestry laboratory of Kebbi State University of Science and Technology, Aliero, Kebbi State. The studies were conducted from February 2020- March 2020 to assess the most effective method of breaking seed dormancy in Dialium guineense seeds. The seeds were subjected to four (4) pre-treatment methods (sulphuric acid, hot water, cold water and mechanical scarification) with untreated seeds as control, the experiment was laid out in completely randomized design (CRD) and replicated three (3) times. Final germination percentage (FGP), germination mean time (GMT), germination index (GRI), Coefficient Velocity of Germination (CVG) and Germination rate index (GRI) were calculated and the data was subjected to the analysis of the variance (ANOVA). Seed treated with cold water for 48 hours (Trt 1) started germination at two (2) days after sowing (DAS) and ended germination at 5 DAS, control and three of the treatments (Trt 2, Trt 5\& Trt 7) started germination at 3 DAS while Trt 4 and Trt 8 started at 4 and 5 DAS respectively. FGP 100\% was obtained from Control and Trt 5 and they finished Germination at 9 and 21 DAS respectively. Highest GI, GRI and CVG and lowest MGT were recorded from Trt 1. The result analysis of findings at 5\% level of statistics showed that there is nosignificant difference between the treatments. Similarly, no germination on seeds in Trt 3 and Trt 6. Seeds of Dialium guineense are not limited by dormancy therefore can be sown without any pre-treatment, but for large scale production of Dialium seedlings it can be treated in cold water at room temperature for 48 hours due to availability and low cost with less risks.
\end{abstract}

Keywords: Dialium guineense, germination, seed dormancy, sowing and pre-germination 


\section{INTRODUCTION}

The most common approach to accelerate plant succession has been to plant seedlings of target species in the established plantations into which the target species had failed to disperse naturally (Hartman et al., 2002). Therefore, the effects of early successional communities (pioneer communities) on target seedlings may differ depending on the habitat provided by the community and the species of seedling (Jensen, 2004). Few studies, however, have highlighted problems which have affected the establishment of indigenous tree seedlings severely when such seedlings are planted in subtropical plantations and shrublands (Anthonia, John and Philip, 2014).

Indigenous tree species are endowed with features that give them potential of ecosystem stabilization and anti desertification control in arid and semi arid area (Rabi'u and Rabi'u, 2013), because they are highly adapted to the environmental conditions. Considering the importance of these indigenous tree species to the populace, livestock and the environment, there is a need to encourage their propagation, since over utilization rendered most of the species threatened.

D. guineense is commonly known as tsamiyar kurmi by the Hausas, Awin among the 'Yorubas' and Icheku by 'Ibos' and (Keay, 1989). It has been classified as a multipurpose tree species by many authors (Okeke and Omaliko, 1991). The fruit contains sweet edible mealy pulp and is consumed locally. Most seeds remain viable for longer periods than normal if they are first dried and then stored at low temperature in a sealed container. The dry wood burns readily and makes splendid firewood while the charcoal is used as fuel wood by blacksmith (Okafor, 1980). Several other domestic uses had been indicated for the wood, the bark and root of the plant are known with medicinal values and when (Gills, 2001).

Despite these numerous economic potentials in traditional culinary, deliberate domestication and silvicultural efforts had remained very low at the expense of diminishing natural population attributed to deforestation and land degradation. Faboye and Gbadamosi (2007) worked on progenies variation while Oboho et al. (2012) worked on the species germination; however their studies used only top soil as potting medium. Developing ex-situ conservation programme for any forest tree species requires sound and broad-based knowledge on the species silvicultural requirements including potting media and pot sizes for nursery operations.

Dormancy is the absence of germination in a mature intact seed under favorable condition of light, temperature, water and oxygen within a specific period of time (Hilhorst, 1995). A viable seed (or other germination unit) is said to be dormant when it does not have capacity to germinate in a specified period of time under normal physical environmental factors that otherwise is favourable to its germination (Aghilan et al., 2014). According to Baskin and Baskin (2001), seed coats can also impose dormancy because they may contain growth inhibitors or may prevent the leaching of inhibitors from the embryo. Pre-germination 
treatments are necessary to speed up germination, seed coat treatments have been used to raise the percentage germination and shorten the period required to reach optimum percentage germination (Willan, 1985).

\section{MATERIALS AND METHODS}

\section{Study Area}

The study was carried out in Kebbi state University of Science and Technology, Aliero. Study site lies on latitude $12^{\circ} 18^{\prime} 22^{\prime \prime} \mathrm{N}$ and Longitude $4^{\circ} 29^{\prime} 35^{\prime \prime} \mathrm{E}$ which covers an area of about $350 \mathrm{~km}^{2}$ (Olajuyigbe et al., 2012). Aliero is inhabited by artisanal community with special interest in onion and pepper farming. The area is dominated by two distinctive seasons: the wet season and the dry season with mean annual rainfall of about $800 \mathrm{~mm}$ and temperatures of about $26^{\circ} \mathrm{C}$. Although, the temperature can go down to about $21^{\circ} \mathrm{C}$ during the harmattan and up to $40^{\circ} \mathrm{C}$ between April and June (Mukhtar, 2016). Suleiman, Noma and Kudiri (2016) highlighted that, the area possessed two important cultivated land namely: dryland (arid - prolong dryness) and fadama (floodplains - significant alluvial clay particles). The vegetation of the area is characterised by few annual grasses, shrubs and scattered trees (Suleiman, 2016) which are threatened by the inhabitants as a result of over exploitation without replacement (Bello and Gada, 2015).

\section{Experimental Materials}

Two hundred and forty (270) viable seeds of Dialium guineense were obtained. The average weight of the seeds for all the species was measured and recorded. Germination assessment will consistof twenty seven (27) observation plots (Petri dishes) and each contained ten (10) viable seeds.

\section{Experimental Procedures}

The research work is comprised of laboratory tests (viability and Germination assessment). Viability Test: The seeds underwent floatation methods. Seeds were soaked in to beaker containing water and observed for ten (10) minutes and viable seeds were identified and allowed to dry before sown. Floatation method is the fastest way of testing seeds viability, which is based on the observation that empty or nonviable seeds float while viable seeds sink or settle down to the bottom of the container (Bello and Gada, 2015).

Germination Assessment: Seeds were subjected to four pre-treatment methods with the untreated seeds as control. The pre-treatment methods are;

(i) Seeds to be soaked in 98\% sulphuric acid concentration for 5, 10 and 15 mins.

(ii) Seeds to be mechanically scarified with sand paper opposite to micropile;

(iii) Seeds to be soaked in cold water for 48 hours

(iv) Seeds to be soaked in boiled water $\left(100^{\circ} \mathrm{C}\right)$ for 5,10 and 15 minutes 


\section{(v) Control (untreated seeds)}

Each treatment combination had 10 seeds, making a total of 270 seeds for the experiment. The pre-treated seeds will be sown in germination dish (GD) moistened with paper towel and to be covered with its lid and placed in thermostat. The germination dish will be arranged in a Completely Randomized Design (CRD) with 10 seeds per GD. Each treatment combination will be replicated in three (3) times.

\begin{tabular}{|c|c|}
\hline Pre-germination treatment & Number of seed treated and sown \\
\hline Cold water for $\mathbf{4 8}$ hours (TRT1) & 30 \\
\hline Mechanical scarification (TRT2) & 30 \\
\hline Conc. $\mathrm{H}_{2} \mathrm{SO}_{4}$ for 5 mins (TRT3) & 30 \\
\hline Conc. $\mathrm{H}_{2} \mathrm{SO}_{4}$ for 10 mins (TRT4) & 30 \\
\hline Conc. $\mathrm{H}_{2} \mathrm{SO}_{4}$ for 15 mins (TRT5) & 30 \\
\hline Hot water $\left(100^{\circ} \mathrm{C}\right) 5 \mathrm{mins}(\mathrm{TRT} 6)$ & 30 \\
\hline Hot water $\left(100^{\circ} \mathrm{C}\right) \mathbf{1 0}$ mins (TRT7) & 30 \\
\hline Hot water $\left(100^{\circ} \mathrm{C}\right) 15 \mathrm{mins}(\mathrm{TRT} 8)$ & 30 \\
\hline Untreated (Control) & 30 \\
\hline
\end{tabular}

Table 1: Treatment combination with number of treated seed

\section{Data Collection and Analysis}

\section{Germination assessment:}

Germination parameters were determined daily (Ajayi and Fakorede, 2000) for a period of thirty days. Six (6) different germination parameters will be assessed. The methodology of calculations of parameters 1, 2, 4 and 6 followed Kader (2005), and 5 followed Ranal et al. (2009).

1. Final germination percentage $(\mathrm{FGP})=$ the total seeds germinated at end of trial/number of initial seeds used 100 times.

2. Mean germination time $(\mathrm{MGT})=\boldsymbol{\Sigma} \mathbf{F x} / \mathbf{\Sigma F}$; where $\mathrm{F}$ is the number of seeds germinated on day $\mathrm{x}$.

3. Coefficient of velocity of germination $(C V G)=\mathbf{N} 1+\mathbf{N} 2+\ldots+\mathbf{N i} / \mathbf{1 0 0} \times \mathbf{N 1 T} 1+\ldots+\mathbf{N i T i}$; where $\mathrm{N}$ is the number of seeds germinated every day and $\mathrm{T}$ is the number of days from seeding corresponding to $\mathrm{N}$.

4. Germination rate index $(\mathrm{GRI})=\mathbf{G} \mathbf{1} / \mathbf{1}+\mathbf{G} \mathbf{2} / \mathbf{2}+\ldots .+\mathbf{G i} / \mathbf{i}$; where $\mathrm{G} 1$ is the germination percentage on day $1, \mathrm{G} 2$ is the germination percentage at day 2 ; and so on.

5. Germination index $(\mathrm{GI})=(\mathbf{1 0} \times \mathbf{N 1})+(\mathbf{9} \times \mathbf{N} 2)+\ldots+(\mathbf{1} \times 10)$; 
where $\mathrm{N} 1, \mathrm{~N} 2 \ldots \mathrm{N} 10$ is the number of germinated seeds on the first, second and subsequent days until 10th day and the multipliers (e.g. 10, 9 ...etc.) are weights given to the days of the germination.

6. Time spread of germination $(\mathrm{TSG})=$ the time in days between the first and last germination events.

The data collected will be subjected to one-way analysis of variance (ANOVA). Treatment means will be separated with Duncan's Multiple Range Test (DMRT). All statistical analyses will be done using SAS software 9.4 version.

RESULT

\begin{tabular}{lllllllll}
\hline TREATMENT & $\begin{array}{l}\text { FGP } \\
(\boldsymbol{\%})\end{array}$ & MGT & GI & CVG & GRI & FDG & LDG & TSG \\
\hline TRT1 & 90 & 4.17 & 866.71 & 24.69 & 22.56 & 2 & 5 & 3 \\
TRT2 & 90 & 7.04 & 726.67 & 14.56 & 12.92 & 3 & 9 & 6 \\
TRT3 & 00 & 00 & 00 & 00 & 00 & 00 & 00 & 00 \\
TRT4 & 93.33 & 8.53 & 793.33 & 12.03 & 7.72 & 4 & 13 & 9 \\
TRT5 & 100 & 5.73 & 830 & 17.74 & 17.74 & 3 & 9 & 6 \\
TRT6 & 00 & 00 & 00 & 00 & 00 & 00 & 00 & 00 \\
TRT7 & 83.33 & 9.04 & 590 & 10.51 & 9.43 & 3 & 19 & 16 \\
TRT8 & 90 & 11.86 & 610 & 8.44 & 7.57 & 5 & 13 & 8 \\
CONTROL & 100 & 15.5 & 740 & 6.47 & 6.73 & 3 & 21 & 18 \\
\hline
\end{tabular}

Table 2: Mean Germination parameters of Dialium guineense

The emergence was recorded at 3 DAS from seeds soaked in cold water (TRT 1) for $48 \mathrm{hrs}$ at room temperature, the mechanically scarified seeds (TRT2), seeds treated with $\mathrm{H}_{2} \mathrm{SO}_{4}$ for 5 mins (TRT5), seeds in hot water at $100^{\circ} \mathrm{C}$ for 10 mins and untreated seeds (control) emerged at 3 DAS, while seeds soaked in acid for 10 mins (TRT4) and those soaked in hot water at $100^{\circ} \mathrm{C}$ for 15 mins recorded their first emergence at 5 and 6 DAS respectively.

The highest FGP (100\%) was recorded from control and TRT5, the lowest $83.33 \%$ was obtained from TRT 7, lowest MGT (4.17) and highest GI (866.71), CVG (24.69) and GRI (22.56) was recorded from TRT 1. Highest MGT (15.5), lowest CVG (6.67), lowest GRI (6.73) was recorded from untreated seed (control) and lowest GI (590) was obtained from TRT 7.

\section{DISCUSSION}

Some of the indigenous tree species seed exhibit dormancy which made them remain dormant for a long period until favourable condition is available through natural or human interference to induce their germination (Turner, 2001). Dormancy can be biologically described as the absence of germination of viable seeds under germination favouring condition (Hilhorst, 1995). As reported by Baskin and Baskin (2004), there are different mechanisms and processes involved in seed dormancy. For a certain tree species, seed 
dormancy can be as a result of hard seed coat which prevents water aeration required to stimulate germination or presence of chemical inhibitor in seed cotyledon (Nwoboshi, 1982).

The analysis of the finding showed that there is no significant difference at $5 \%$ level of significance between the germination parameters but treatment with lowest MGT, highest GRI, lowest GI and lowest CVG was chosen as suggested by Scott et al. (1984). The higher the FGP value, the greater the germination of seed population, the lower the MGT value, the faster a population of germinated seeds (Ochard, 1977); Kader (1998) reported that, Lower FDG value indicates a faster germination and Lower LDG values indicates faster ending of germination. Similarly, higher CVG value indicates germination rapidity (Jones and Sanders 1987) while higher GRI value indicate higher and faster germination (Esechi, 1994), and higher GI value denotes higher percentage and rate of germination (Bench Arnold et al., 1991). Furthermore, Kader (1998) suggested that, the higher the TSG value, the greater the difference in germination speed between fast and slow germination members of a seedlot.

In this study, the seed emergence was first observed at 2 DAS from the seed soaked in cold water (TRT1) for 48 hours as against the other treatments ( TRT2, TRT5, TRT7 and control) which germinated in 3 DAS while in TRT4 and TRT5 emergence started at 4 \& 5 DAS respectively. The finding of the present study agreed with Olajide et al. (2014) that reported, soaking seed of $D$. guineense in cold water for 24 hours is cheap and effective as it enhanced seed water inhibition and lessened its days of emergence. It is also supported by Offiong et al. (2010) findings that soaking Tectona grandis in cold water for 48 hours was best in pregermination treatment as it shortened the number of emergence day. Furthermore, this finding agreed with Nwaoguala et al. (2007) that enhanced D. guineense emergence with $37.7 \%$ using $\mathrm{H}_{2} \mathrm{SO}_{4}$ as seed treatment. In the work Girase et al. (2002), germination trail of treated Acacia nilotica was best obtained (80\%) using hot water. The most effective method of this study is soaking D. guineense seeds in cold water for 48 hours as it softened the seed coat and drained off chemical inhibitor that might be present by water, thereby shortening the number of days that would naturally have required for the seeds to germinate.

\section{CONCLUSION}

Dialium guineense seed possessed hard seed coat and it requires scarification to start germinating, and soaking its seed in cold water for 48 is a cheap and most effective way to break its dormancy. 


\section{REFERENCES}

Ajayi, S.A. and Fakorede, M.A.B. (2000). Physiological Maturity Effects on Seed Quality. Seedling vigour and mature plant characteristics of maize in a tropical environment. Seed Sci. Technol. 28: 301-309

Anthonia, N. R., John, S. T. and Philip, R. A. (2014). Propagation and seedling establishment of selected multipurpose woody species of Uganda. International Journal of Biodiversity Science, Ecosystem Services \& Management. 10 (4): 270-274 https://doi.org/10.1080/21513732.2014.953584

Baskin, J.M. and Baskin, C. C. (2004). A classification system for seed dormancy. Seed Science and Research 14 (1): 1-16.

Bello, A.G. and Gada Z.Y. (2015). Germination and early growth assessment of Tamarindus indica $L$ in Sokoto State, Nigeria Hindawi Publishing CorporationInternational. Journal of Forestry Research. Article ID 634108, 5 pages.

Bench A.R., Fenner, M. and Edwards, P., (1991). Changes in germinability, ABA content and ABA embryonic sensitivity in developing seeds of Sorghum bicolor (L.) Moench induced by water stress during grain filling. New Phytologist, 118, 339-347.

Esechie, H., (1994). Interaction of salinity andtemperature on the germination of sorghum.Journal of Agronomy and Crop Science, 172,194-199.

Faboye,O.O and Gbadamosi, A (2007). Variation studies in progenies of Dialium guineense Wild. Nigerian Journal of Ecology Vol. 8:6 - 11

Gills, L.S. (1992). Ethnobotanical uses of plants in Nigeria. University of Benin, Press 276p

Girase, U. S., Jambhale, N. D and Suryawanshi, Y. B. (202). Germination and seed dormancy studies in Acacia species. Seed-Research 30 (1) :39-42.

Hartmann, H.T and Kester, D. E. (1975). Plant Propagation Principles and Practices. Prentice. Hal. Inc, Englewood Cliffs, New JerseyPP 662.

Hilhorst, H.W. (1995). A critical update on seed dormancy. I. Primary dormancy. Seed Science Research. 5(2):61-73

Jensen K. (2004). Dormancy patterns, germination ecology, and seed bank types of twenty temperate fen grassland species. WETLANDS: The Society of Wetland Scientists, 24 (1): 152-166.

Jones, K. and Sanders, D., (1987). The influence of soaking pepper seed in water or potassium salt solutions on germination at three temperatures. . Journal of Seed Technology, 11, 97-102 
Kader (Al-Mudaris), M., (1998). Notes on various parameters recording the speed of seed germination. Journal of Agriculture in the tropics and Subtropics, 99, 147-154

Kader, M. A. (2005). A Comparison of Seed Germination Calculation Formulae and the Associated Interpretation of Resulting Data. Journal \& Proceedings of the Royal Society of New South Wales, Vol. 138, p. 65-75, ISSN 0035-9173/05/020065

Keay R, W.J (1989) Trees of Nigeria: Published in the United States (Oxford University Press)

Mukhtar, R.B. (2016): Influence of light intensity on early growth of Adansonia digitata (L.). Research Journal of Recent Sciences. 5(12): 5-9.

Nwaoguala, C.N.C, Osaigbovo, A.U. and Orhue, E.R. (2007). Seed treatment for development of seedlings of Black Velvet Tamarind (Dialium guineense). African Journal of General Agriculture 3:49 - 51.

Nwoboshi, L.C. (1982). Tropical Silviculture. Ibadan University Press

Oboho,E.G and Ogana, F.N (2012). Effect of varying hot water temperatures on the Germination and early growth of Dialium guineense (Wild) seeds. Annals. Of Bio. Res. 3(3) 1247-1254

Offiong, M.O., Udofia, S.I., Olajide, O. and Ufot, I.N. (2010) Comparative Study of PreGermination Treatments and Their Effects on the Growth of Tectona grandis (Linn. F) Seedlings. African Research Review, 4, 368-378.

Okafor J.C (1997). The place of the Wild (uncultivated) fruits and vegetables in the Nigeria Diet proceeding of National Seminar on Fruits and Vegetables, Ibadan, Nigeria 13th $17^{\text {th }}$ October 1995 pg. 262-297. $8^{\text {th }}$ Edition.

Okeke, A.I and Omaliko, C.P.E (1991). Effects of Nitrogen and Phosphorus fertilizer rates on the growth of Dialium guineense Wild seedlings.Nig Jour. Of For. Vol.27, No1.

Olajide, O., Oyedeji, A.A., Tom, G.S. andkayode, J (2014). Seed Germination and Effectsof three Watering Regimes o the Growth of Dialium guineense (WILD) Seedlings. American Journal of Plant Science. Published online

Olajuyigbe, S.O., Jimoh, S.O., Adegeye, A.O. and Mukhtar, R.B. (2012). Drought stress on early growth of Diospyros mespiliformis (Hochst ex. A.) in Jega, Northern Nigeria. Nigerian Journal of Ecology, 12(1): 71-76.

Orchard, T., (1977). Estimating the parameters of plant seedling emergence. Seed Science and Technology, 5, 61-69.

Scott, S., Jones, R. and Williams, W., (1984). Review of data analysis methods for seed germination. Crop Science, 24, 1192-1199 
Suleiman, U. (2016). Surface soil factors and soil Characteristics in the geophysical milieu of Kebbi State. Eurasian Journal of soil science. 5(3):209-220

Turner, I.N. (2001) The Ecology of Trees in the Tropical Rainforest. Cambridge University Press, Cambridge, 298 p.

http://dx.doi.org/10.1017/CBO9780511542206 